\title{
Environmental life cycle assessment of yellow mealworm (Tenebrio molitor) production for human consumption in Austria - a comparison of mealworm and broiler as protein source
}

\author{
Moritz Dreyer $^{1}$ - Stefan Hörtenhuber ${ }^{2} \cdot$ Werner Zollitsch $^{2} \cdot$ Henry Jäger $^{3} \cdot$ Lisa-Marie Schaden $^{4}$ - Andreas Gronauer ${ }^{1}$. \\ Iris $\mathrm{Kral}^{1}{ }^{10}$
}

Received: 23 December 2020 / Accepted: 14 September 2021 / Published online: 7 October 2021

(c) The Author(s) 2021

\begin{abstract}
Purpose Global food production needs to increase to provide enough food for over 9 billion people living by 2050. Traditional animal production is among the leading causes for climate change and occupation of land. Edible insects might be a sustainable protein supply to humans, but environmental life cycle assessment (LCA) studies on them are scarce. This study performs an LCA of a small-scale production system of yellow mealworms (Tenebrio molitor) in Central Europe that are supplied with organic feedstuff.

Methods A combined ReCiPe midpoint $(\mathrm{H})$ and $\mathrm{CED}$ method is used to estimate the potential environmental impacts from cradle-to-gate. Impact categories include global warming potential (GWP), non-renewable energy use (NREU), agricultural land occupation (ALOP), terrestrial acidification potential (TAP) and freshwater eutrophication potential (FEP). The robustness of the results is tested via sensitivity analyses and Monte Carlo simulations.

Results and discussion Impacts related to the production of $1 \mathrm{~kg}$ of edible mealworm protein amount to $20.4 \mathrm{~kg} \mathrm{CO}_{2}$-eq (GWP), 213.66 MJ-eq (NREU), $22.38 \mathrm{~m}^{2}$ (ALOP), $159.52 \mathrm{~g} \mathrm{SO}_{2}$-eq (TAP) and $12.41 \mathrm{~g} \mathrm{P-eq} \mathrm{(FEP).} \mathrm{Upstream} \mathrm{feed} \mathrm{produc-}$ tion and on-farm energy demand related to the heating of the facilities are identified as environmental hot-spots: Depending on the impact category, feed supply contributes up to $90 \%$ and on-farm heating accounts for up to $65 \%$ of overall impacts. The organic mealworm production system is contrasted with a selected Austrian organic broiler production system, to which it compares favourably (18-72\% lower impacts per category), with the exception of freshwater eutrophication (6\% higher impacts).

Conclusions This case study shows that the Austrian mealworm production system compares favourably to traditional livestock systems. Compared to LCAs from large-scale T. molitor rearing facilities in France and in the Netherlands, however, the Austrian production system cannot compete for the reasons of production scale, feed conversion efficiency and type of production system. Nevertheless, the investigated mealworms represent a sustainable protein alternative that should be added to the Western diet.
\end{abstract}

Keyword Life cycle assessment (LCA) · Sustainability assessment · Edible insects · T. molitor Alternative protein sources $\cdot$ Feed conversion efficiency

\section{Introduction}

Environmental impacts from food production are unavoidable. Providing human-edible proteins via animal production makes up a major impact within the food and

Communicated by Thomas Jan Nemecek

Iris Kral

iris.kral@boku.ac.at

Extended author information available on the last page of the article agricultural sector (Steinfeld et al. 2006). With a 14-18\% share of global greenhouse gas (GHG) emissions, livestock production substantially contributes to climate change (Gerber and FAO 2013; Herrero et al. 2016). Although grazing ruminants increase global food supply when converting pasture into edible proteins, $77 \%$ of agricultural land is attributed to livestock production - especially due to feed crop cultivation - while farmed animals only supply one third of global protein intake with meat and dairy products (Herrero et al. 2013; FAO 2017). 
However, as consumption of animal products increases with rising income and urbanisation (Tilman and Clark 2014), per capita meat consumption is growing in countries with strong economic transition and remaining high in industrialised countries (Gerber and FAO 2013). The world's population is expected to rise from today's 7.6 billion to 9.8 billion people in 2050 (United Nations 2017). Taking into account both, population growth and shifting diets, the adequate provision of food by midcentury will require an increase of global food production by more than 56\%, compared to 2010 (World Resources Institute 2013).

Hence there is a need of closing this food gap and simultaneously reducing the environmental impacts from the food sector, also referred to as "the Great Balancing Act" (Searchinger et al. 2014). Within a range of potential solutions to face this challenge (see Searchinger et al. 2014), one potential contribution might be the substitution of high-impact animal products with protein alternatives based on plant material (e.g. soy, wheat, pulses), upcoming food products (e.g. blue-green algae, fungi, cultured meat) or potentially low-impact mini-livestock products such as edible insects.

This study emphasizes on the sustainability aspects of the latter. Over 2,000 insect species are documented as edible and more than two billion people are eating insects on a regular basis, especially in the Global South and in tropical regions (Jongema 2015). Numerous species are not only rich in proteins but also in essential minerals and trace elements (van Huis et al. 2013; Payne et al. 2016; Grau et al. 2017). The production of edible insects also promises to have low impacts on the environment, yet only a handful of life cycle assessment (LCA) studies have documented this (Oonincx and de Boer 2012; Miglietta et al. 2015; Smetana et al. 2016; Halloran et al. 2017; Thévenot et al. 2018). To the knowledge of the authors an LCA of a smallscale production system of yellow mealworms (Tenebrio molitor) with a special focus on organic feed supply and a regional reference to Central Europe has not been conducted before.

The main purpose of this study which is based on Dreyer (2019) is (1) to assess the potential environmental impacts related to an Austrian organic production system of edible mealworms; (2) to identify environmental hot-spots along the production chain; and (3) to compare T. molitor production to a selected Austrian organic broiler production system.

\section{Methods}

As the production of mealworms (main LCA) was benchmarked to broiler production (comparative LCA), two attributional LCAs were conducted in accordance with ISO
14040 and 14044 standards (ISO 2006a, b) and coherent life cycle design (Guinée 2002; Notarnicola et al. 2015).

\subsection{Goal and scope}

The aim of this case study is to assess the potential environmental impacts of the production of T. molitor larvae for human consumption. Despite a rapid increase in plant-based alternatives, products of animal origin are the most important source of protein for Austrian consumers, accounting for $67 \%$ of total protein supply (calculated based on Rust et al. 2017). Chicken meat is considered as being more sustainable (in terms of production efficiency) than meat from other livestock (de Vries and de Boer 2010; Gerber and FAO 2013; Cesari et al. 2017). For these reasons, the production of broilers was chosen in a comparative LCA to serve as an animal-based benchmark for mealworm production.

\subsubsection{Systems studied}

Primary data for the main LCA (mealworm production) were sourced from a small-scaled organic mealworm production site in southern Austria about 1,000 m above sea level. Within a climate-controlled rearing system, temperature levels are kept above $25^{\circ} \mathrm{C}$ and humidity above $60 \%$. Operating on a small scale, the facility stores around 500 homogeneous food standard boxes containing mostly mealworm larvae, but also parental beetles (Fig. 1), making it a self-sustaining system (Mealworm producer, pers. comm., 2018 October $25^{\text {th }}$ ).

\subsubsection{Functional unit}

The main purpose of adding edible insects to the Western diet is to provide a protein alternative, so the

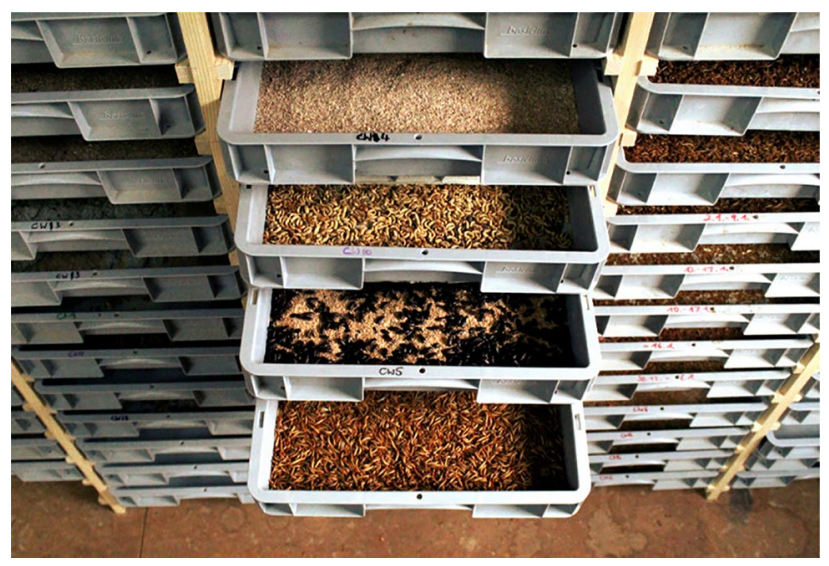

Fig. 1 The investigated production system: Selected rearing boxes containing T. molitor beetles and larvae of various ages 
nutritionally-based functional unit (FU) of $1 \mathrm{~kg}$ of protein serves as reference for this study. Mealworm protein was estimated as the amount of nitrogen (analysed by both Kjeldahl und Dumas method) multiplied by 6.25, a typical conversion factor that is also used for insects (Miglietta et al. 2015; Halloran et al. 2017). Protein content of Austrian mealworms was calculated at $53.78 \%$ on a dry matter (DM) basis. As nitrogen not only occurs in proteins but is also bound in the chitin of the mealworm's exoskeleton, determined average nitrogen values were subtracted based on reported values of chitin-bound nitrogen of 5-6\% (Barker et al. 1998; Ng et al. 2001). Taking into consideration the DM content when harvested (27\%) and an edible portion of $94.5 \%$ (without chitin), $1 \mathrm{~kg}$ of mealworm protein requires $7.30 \mathrm{~kg}$ of liveweight mealworm mass.

Crude protein content of typical slow growing Austrian organic broilers of genotype ISA-JA-757 (Schmidt et al. 2009 ) is reported to be $51.5 \%$ on a DM basis (Hörtenhuber and Zollitsch 2016). Considering DM content (33\%) and the proportion of edible boneless meat (43\%) (Gac et al. 2012), $1 \mathrm{~kg}$ of broiler protein requires $5.89 \mathrm{~kg}$ of broiler meat and $13.70 \mathrm{~kg}$ of broiler live weight, respectively. The quality of mealworm and broiler protein was assumed to be comparable since a PDCAAS (Protein Digestibility Corrected for Amino Acid Score) of 0.86 has been analysed for $T$. molitor indicating that mealworms can meet human dietary requirements (Poelaert et al. 2018).

\subsubsection{System boundaries}

A cradle-to-gate approach was chosen, assessing the potential environmental impacts up to the product being ready for purchase, i.e. the transport from the production site and the meal preparation are not included. The systems account for the feeding of the parent stocks, as well as the processes of oviposition (mealworms) and hatchery (broilers), respectively. Selection and acquisition of the initial parent stocks are not included. Concerning feed supply, system boundaries include soil preparation and cultivation of the feed ingredients, with the exception of brewer's yeast being considered a residue from the beer brewing industry with no environmental burdens attached (apart from transportation and drying of the liquid yeast), as it has been done in previous mealworm LCAs (Oonincx and de Boer 2012; Joensuu and Silvenius 2017). After being killed by deep-freezing, mealworms are blanched to eliminate potential pathogens and to enhance preservation (Mealworm producer, pers. comm., 2018 October $25^{\text {th }}$ ). For broilers, the system boundary ends after slaughtering, cleaning the carcass and removing bones and inedible body parts (Gac et al. 2012), in the system diagram (Fig. 3) summarised as "slaughtering \& preserving". Mealworms are eaten as a whole, yet chitin was subtracted from final weight to correspond with the FU of boneless broiler meat (see 2.1.2). In both systems, materials used for product packaging and transportation to retail are not included. An overview of the analysed mealworm production system is given in Fig. 2.
Fig. 2 System diagram of the Austrian mealworm production system with $1 \mathrm{~kg}$ of protein as functional unit (FU). Boxes indicate the various products or processes, while arrows represent flows of energy or products. Feed and energy also flow into parent stock and oviposition, but for reasons of clarity, these boxes are not connected with arrows

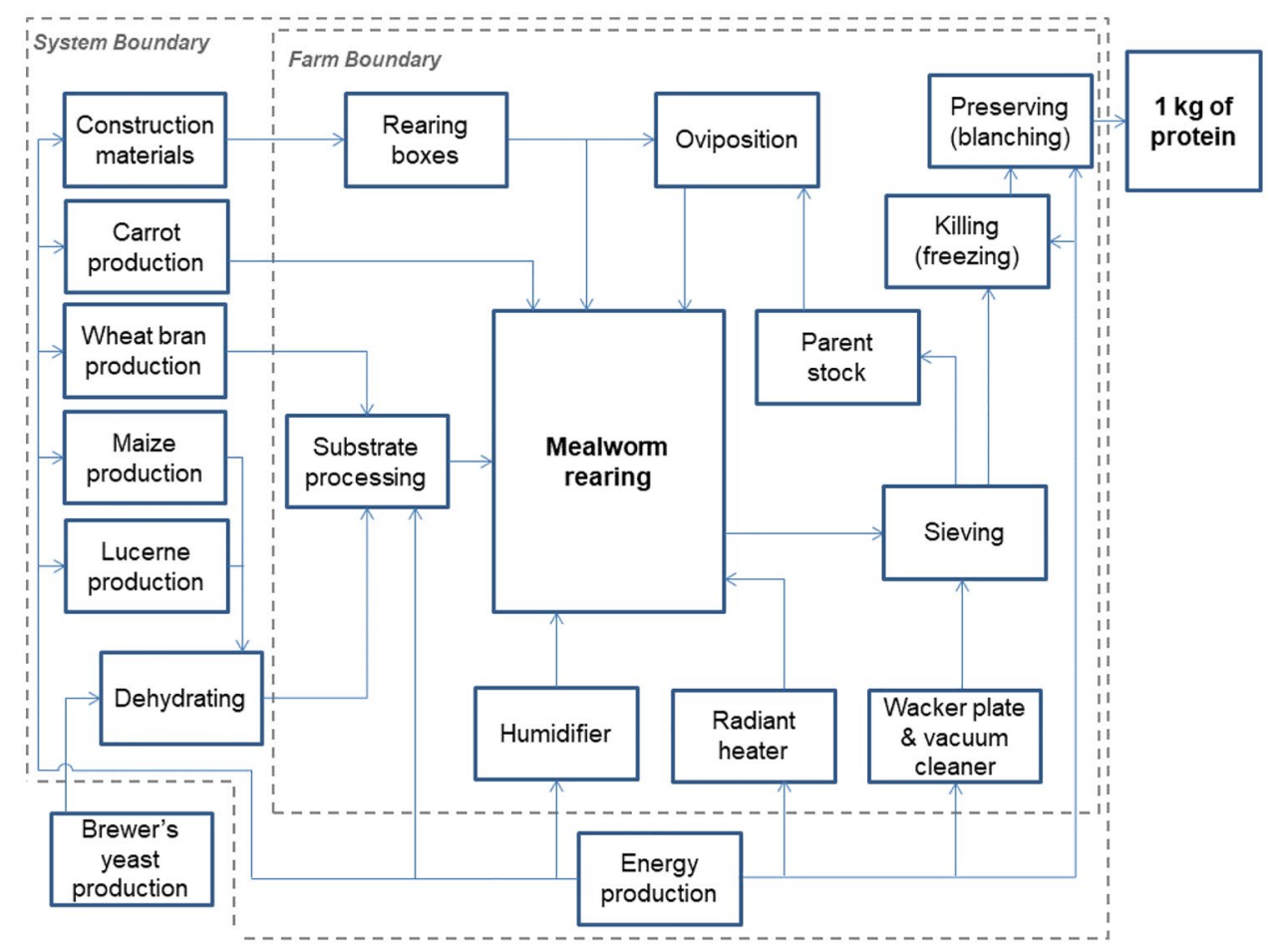


Fig. 3 System diagram of the modelled Austrian broiler production system with $1 \mathrm{~kg}$ of protein as functional unit (FU). Feed and energy also flow into parental stock and hatchery, but for reasons of clarity, these boxes are not connected with arrows

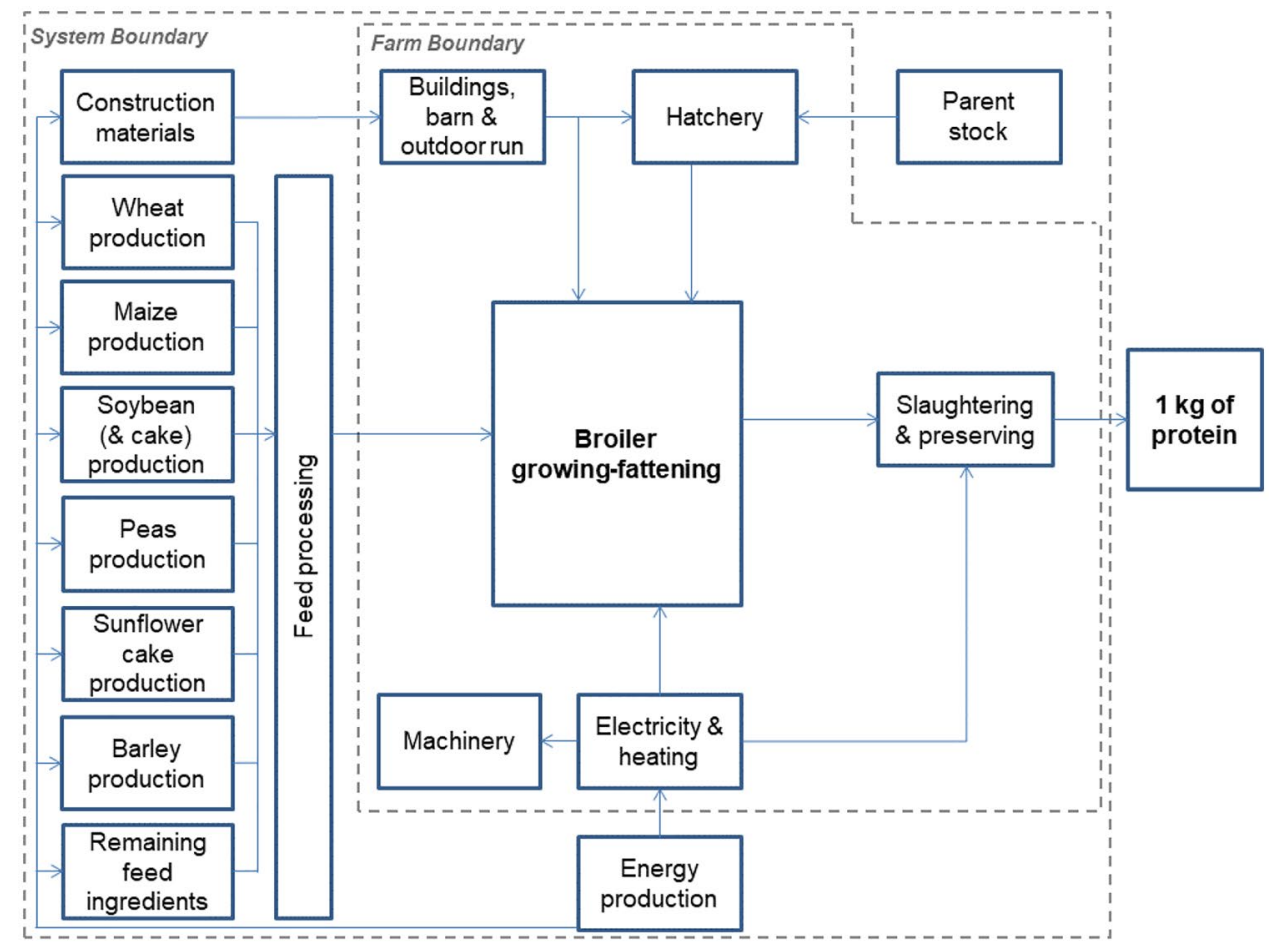

An overview of the analysed broiler production system is illustrated in Fig. 3.

\subsubsection{Methods, software and databases}

Environmental impact categories chosen are global warming potential (GWP), non-renewable energy use (NREU), agricultural land occupation (ALOP), terrestrial acidification potential (TAP) and freshwater eutrophication potential (FEP). The five categories were quantified using the impact assessment method ReCiPe 2008 midpoint (H) (Goedkoop et al. 2008), adapted according to recent IPCC guidelines (IPCC 2013) in order to resemble ReCiPe midpoint 2016 and supplemented with the method of cumulative energy demand (CED) (Wolf et al. 2012). Calculations were performed via openLCA 1.7.0 software (Green Delta GmbH 2019) sourced from Ecoinvent v3.2 (Ecoinvent 2015) and Agribalyse v1.3 (Koch and Salou 2016) databases.

The impact category ALOP was expanded with space requirements for farm buildings and the provided indoor space and outdoor run for the animals (the latter only for broilers). These sealed surfaces were defined as "arable land occupation" to be visible within the agriculture-related impact category. The land used for energy and material production was assumed negligible, thus this category doesn't claim to reflect the overall picture of production-related land consumption.

\subsubsection{Allocation}

The mealworm system consists of two multiple-outputprocesses calling for allocation (Guinée 2002): (1) The production of edible mealworms (main product) and the accumulation of manure (co-product). The impacts of the mealworm production were fully allocated to the mealworms, as it has been done in comparable LCA studies (Oonincx and de Boer 2012; Thévenot et al. 2018). (2) Grinding of wheat grain yields both wheat flour and wheat bran, i.e. the feed ingredient wheat bran originates as a byproduct (16\% of grain mass) from wheat flour production. Economic allocation was applied for wheat bran: $2.1 \%$ of the impacts related to wheat grain production were economically allocated to the bran (based on its economic value in relation to that of flour).

\subsubsection{Uncertainty and sensitivity}

To test the robustness of the LCA results with regards to the variability and uncertainty of input data, uncertainty analysis was performed with Monte Carlo simulations. Based on assumed probability distribution functions for critical model input parameters, this method relies on repeated random sampling of these values leading to an overall approximation of output uncertainty (Kral et al. 2016). For the two systems studied herein, Monte Carlo simulations were conducted with 1,000 iterations. Statistical significance 
( $\alpha=0.05$ ) of differences between the systems was tested with a Mann-Whitney $U$ test using SPSS (IBM Corp. 2016).

Two alternative scenarios were performed to analyse their influence on the overall results: (1) "Improved FCR": As other mealworm LCAs (Oonincx and de Boer 2012; Thévenot et al. 2018) indicate better values on feed conversion ratios (FCR) than the investigated mealworm production, it has been tested how reduced feed input would affect the overall impacts. (2) "Colder winter": As heating-related energy consumption appeared to be of high relevance for the mealworm production, it has been tested how sensitive the system is to even higher heating demands due to potentially decreased outdoor temperatures in the winter season.

\subsection{Life cycle inventory}

\subsubsection{Mealworm system}

Inventory for mealworm production is based on primary data from five separate breeding cycles (beginning every two weeks) gathered by on-site and remote investigation (data collection, measurements and estimations) between July 2018 and February 2019. The average duration of the mealworm rearing phase is based on primary data and was 100 days (parent stock included). Generic input flows and processes from Ecoinvent v3.2 [which is the only version that can be combined with Agribalyse] (Ecoinvent 2015) and Agribalyse v1.3 (Koch and Salou 2016) datasets were adapted to Austrian conditions. Data not available or calculable were obtained from literature (Table 1).
The feed composition includes wheat bran $(70 \%)$, maize (12\%), brewer's yeast (10\%) and lucerne (8\%) - all from organic production. In addition to this dry substrate, mealworms are fed with organic carrots as their only source of water (apart from air moisture). They are eaten as a whole resulting in a net-FCR of 3.61 (carrots excluded).

Generic input flows from feed datasets were adapted to the actual mealworm feed composition. The wheat bran arising in an Austrian mill mainly derives from wheat grains cultivated in Austria. Maize grain comes from an Austrian distributor, but as its origin could not be precisely tracked, data on energy demand were broadened for Europe. As the mealworms are fed with lucerne from Bavaria, the energy required for plant dehydration was corrected for Germany. Brewer's yeast arises from the beer brewing process and is considered a residue from the food industry, as it has been done in previous mealworm LCAs (Oonincx and de Boer 2012; Joensuu and Silvenius 2017). Only the heating energy needed for drying the liquid brewer's yeast was taken into account (Van Zeist et al. 2012), putting the production outside the system boundary in the system diagram (Fig. 2). Supplemented carrots are cultivated at the Czech-Austrian border. The arable land used for feed cultivation was adapted for each feed input according to yield per hectare indicated for Austrian organic production (KTBL 2015). Transportation from field to mealworm farm gate was assessed for all feed ingredients.

On-farm energy use for electric appliances (electric heater, humidifier, wacker plate, vacuum cleaner) and feed processing devices (mill and mixing machine) were recorded via customary and customized power meters. Temperature

Table 1 Inputs and outputs of the mealworm system indicated per $\mathrm{kg}$ of both edible mealworm mass and protein

\begin{tabular}{|c|c|c|c|c|c|c|}
\hline & Production stage & Flow & Edible mass & Edible protein & Unit & Data source \\
\hline \multirow[t]{9}{*}{ Input } & \multirow[t]{3}{*}{ Feed supply } & Dry feed & $\begin{array}{l}3.61 \\
(=\mathrm{FCR})\end{array}$ & 26.33 & {$[\mathrm{~kg}]$} & Own calculations $^{\mathrm{A}}$ \\
\hline & & Carrots & 2.78 & 20.28 & {$[\mathrm{~kg}]$} & \\
\hline & & Feed processing (on-farm) & 0.04 & 0.32 & {$[\mathrm{MJ}]$} & Own measurements ${ }^{\mathrm{A}}$ \\
\hline & \multirow[t]{4}{*}{ Rearing } & Rearing facility & 0.02 & 0.15 & {$\left[\mathrm{~m}^{2}\right]$} & Own calculations ${ }^{\mathrm{A}}$ \\
\hline & & Rearing boxes (PPC) & 0.03 & 0.23 & {$[\mathrm{~kg}]$} & Own estimation $^{\mathrm{A}}$ \\
\hline & & Electric heater & 10.38 & 75.67 & {$[\mathrm{MJ}]$} & Own measurements ${ }^{\mathrm{A}}$ \\
\hline & & $\begin{array}{l}\text { Humidifier, wacker plate and } \\
\text { vacuum cleaner }\end{array}$ & 0.09 & 0.67 & {$[\mathrm{MJ}]$} & \\
\hline & \multirow[t]{2}{*}{ Killing \& preserving } & Freezing & 0.22 & 1.60 & {$[\mathrm{MJ}]$} & \\
\hline & & Blanching & 1.65 & 12.03 & {$[\mathrm{MJ}]$} & $\begin{array}{l}\text { Own calculations based } \\
\text { on Oberascher et al. } \\
(2011)\end{array}$ \\
\hline \multirow[t]{4}{*}{ Output } & \multirow[t]{3}{*}{ Rearing } & $\mathrm{N}_{2} \mathrm{O}$ (animal-related) & 25.50 & 185.98 & {$[\mathrm{mg}]$} & Oonincx et al. (2010) \\
\hline & & $\mathrm{NH}_{3}$ (animal-related) & $<1$ & $<1$ & {$[\mathrm{mg}]$} & \\
\hline & & Manure & 2.18 & 15.89 & {$[\mathrm{~kg}]$} & Own calculations $^{\mathrm{A}}$ \\
\hline & Total system output & Killed \& preserved mealworms & 1 & $7.30^{\mathrm{B}}$ & {$[\mathrm{kg}]$} & \\
\hline
\end{tabular}

A: Based on data collected from mealworm producer (pers.comm.)

B: Corresponding to $1 \mathrm{~kg}$ of edible protein 
levels of above $25^{\circ} \mathrm{C}$ are kept steadily by an electric heater. The heating period (October 2018 to January 2019) was affected by unusual climate conditions, but it was assumed that the untypically warm autumn (ZAMG 2018a, b) and the extremly cold January (ZAMG 2019) would balance out. Annualised assumptions resulted in heating-related electricity use per $\mathrm{kg}$ of live mealworm of $10.38 \mathrm{MJ}$. Contributions of the remaining appliances are comparatively low, the same is true for feed processing. Mealworms are killed by freezing and blanched to be preserved (Table 1). The average Austrian electricity mix was used, which is a conservative approach as the mealworm farm is supplied with electricity from $100 \%$ hydropower, causing even less environmental impacts.

Under continuous operation a durability of 7.5 years was assumed for the rearing boxes (EN standardised food boxes) made from polypropylene carbonate (PPC). No construction material was attributed to the insulated rearing container, as it is made from recycled wooden boards (Mealworm producer, pers. comm., 2018 August 30th). Space requirements per $\mathrm{kg}$ of live mealworms were calculated by dividing the total rearing facility area by the annual yield. Water consumption for cleaning the rearing facilities was calculated at $1 \mathrm{~L}$ per kg mealworm produced and considered negligible when comparing with quantities needed for food crop irrigation. In terms of animal-related emissions, no $\mathrm{CH}_{4}$ arises when rearing mealworms (Hackstein and Stumm 1994) and data on direct $\mathrm{N}_{2} \mathrm{O}$ and $\mathrm{NH}_{3}$ emissions were taken from Oonincx et al. (2010).

Flow quantities related to the mealworm production system are summarised in Table 1.

\subsubsection{Organic broiler system}

The inventory for broiler production is based on generic data adapted to Austrian conditions to be comparable to the mealworm production. Agribalyse v1.3 (Koch and Salou 2016) process Meat, for food, from broiler, at plant was sourced with Broiler, organic, at farm gate for the breeding and Broiler, slaughter, processing for the slaughtering. Data are supplied with Ecoinvent v.3.2 (Ecoinvent 2015).

Feed input of $2.11 \mathrm{~kg}$ (as fed basis) per kg live weight was assumed for typical Austrian organic broilers (Bellof and Schmidt 2007). With an edible portion (boneless meat) of $43 \%$ (Gac et al. 2012) the net-FCR was calculated at 4.91 . Mean duration of the growing-fattening phase for Austrian organic broilers is assumed to be 57 days (Bellof and Schmidt 2007). As they need significantly less breeding days than their French counterparts (Koch and Salou 2016) for the same final live weight $(2.3 \mathrm{~kg})$, on-farm emissions of the original dataset were adapted accordingly.

Feed ingredients of the Agribalyse dataset were replaced by a typical feed composition for Austrian organic broilers: Wheat (20\%), maize (19\%), soybean (14\%), peas (13\%), sunflower cake (12\%), barley (11\%), soybean cake (3\%), corn gluten ( $2 \%$ ), sunflower oil ( $2 \%$ ), calcium phosphate, sodium chloride, salt and a mineral-vitamin premix (together $<5 \%$ ) (Bellof and Schmidt 2007). The arable land used for the cultivation of the feed was determined according to plant yield per hectare (KTBL 2015). Transport of feed materials ranges from its origins to the broiler farm.

All forms of energy required for heating and cooling of the buildings as well as for operating the machinery are

Table 2 Inputs and outputs of the broiler system indicated per kg of both edible broiler meat and protein

\begin{tabular}{|c|c|c|c|c|c|c|}
\hline & Production stage & Flow & Edible meat & Edible protein & Unit & Data source \\
\hline \multirow[t]{7}{*}{ Input } & Feed supply & $\begin{array}{l}\text { Feedstuffs according to diet } \\
\text { composition }\end{array}$ & $\begin{array}{l}4.91 \\
(=\mathrm{FCR})\end{array}$ & 28.92 & {$[\mathrm{~kg}]$} & Bellof \& Schmidt (2007) \\
\hline & \multirow[t]{4}{*}{ Growing-fattening } & Rearing facilities and outdoor run & 0.97 & 5.73 & {$\left[\mathrm{~m}^{2}\right]$} & $\begin{array}{l}\text { Own calculations based on BIO } \\
\text { AUSTRIA (2015) }\end{array}$ \\
\hline & & Construction materials ${ }^{\mathrm{A}}$ & 0.03 & 0.19 & {$\left[\mathrm{~m}^{2}\right]$} & \multirow{5}{*}{$\begin{array}{l}\text { Agribalyse v1.3 and Ecoinvent } \\
\text { v3.2 }\end{array}$} \\
\hline & & Electricity for machinery & 0.78 & 4.62 & {$[\mathrm{MJ}]$} & \\
\hline & & Heating & 10.38 & 61.14 & {$[\mathrm{MJ}]$} & \\
\hline & \multirow[t]{2}{*}{ Slaughtering \& preserving } & Electricity & 2.40 & 14.13 & {$[\mathrm{MJ}]$} & \\
\hline & & Heating & 3.49 & 30.58 & {$[\mathrm{MJ}]$} & \\
\hline \multirow[t]{7}{*}{ Output } & \multirow[t]{6}{*}{ Growing-fattening } & $\mathrm{N}_{2} \mathrm{O}$ (animal-related) & 2.41 & 14.19 & {$[\mathrm{~g}]$} & \\
\hline & & $\mathrm{NH}_{3}$ (animal-related) & 32.25 & 190.04 & {$[\mathrm{~g}]$} & \\
\hline & & $\mathrm{CH}_{4}$ (animal-related) & 3.35 & 19.71 & {$[\mathrm{~g}]$} & \\
\hline & & Nitrate (animal-related) & 13.77 & 81.15 & {$[\mathrm{~g}]$} & \\
\hline & & Nitrous oxide (animal-related) & $<1$ & $<1$ & {$[\mathrm{~g}]$} & \\
\hline & & Manure & 14.13 & 83.28 & {$[\mathrm{~kg}]$} & LfL (2018) \\
\hline & Total system output & Slaughtered \& preserved broilers & 1 & $5.89^{\mathrm{B}}$ & {$[\mathrm{kg}]$} & \\
\hline
\end{tabular}

A: Expressed in $\mathrm{m} 2$ of built up stable area but pre-processes include material for buildings, primarily steel and polyester

B: Corresponding to $1 \mathrm{~kg}$ of edible protein 
included (Koch and Salou 2016). For feed supply, broiler production and slaughtering, energy forms of heat and electricity provision were adapted to Austrian or, if not available, to comparable Swiss conditions. Other inputs considered are the construction of the buildings (siding, roofing and ventilation) and the storage areas (shed, barn and garage). No infrastructure, but heat and electricity is assessed for slaughtering (Koch and Salou 2016). Account has been taken of the fact that Austrian organic broilers are offered a larger housing area (BIO AUSTRIA 2015).

Flow quantities related to the broiler production system are summarised in Table 2.

\section{Results and discussion}

\subsection{Mealworm system}

The potential environmental impacts associated with $T$. molitor production are presented in Table 3 .

The production of $1 \mathrm{~kg}$ of edible mealworm protein (FU) resulted in $20.4 \mathrm{~kg} \mathrm{CO}_{2}$-eq of global warming potential (GWP), 213.66 MJ-eq of non-renewable energy use (NREU), $22.38 \mathrm{~m}^{2}$ of agricultural land occupation (ALOP), $159.52 \mathrm{~g}$ $\mathrm{SO}_{2}$-eq of terrestrial acidification potential (TAP) and $12.41 \mathrm{~g}$ P-eq of freshwater eutrophication potential (FEP).

Figure 4 shows the relative contributions of the sources "feed supply", "rearing" and "killing \& preserving" to the impacts of the production of mealworm protein. The production and provision of mealworm feed greatly contributes to ALOP (90\%) and TAP (87\%), to a lesser extent to GWP (49\%) and NREU (44\%) and comparatively little to FEP (24\%). Rearing the mealworms contributes most to FEP (65\%), almost half to NREU (49\%) followed by GWP (44\%) and hardly to TAP (11\%) and ALOP (9\%). Impacts from the killing process are relatively small, ranging from negligible contributions to ALOP (1\%) and TAP (2\%), a little more to GWP and NREU (7\% each) to $11 \%$ to FEP.

GWP - feed supply: Almost half of total GHG emissions (49\%) from T. molitor production arise from the feed supply.
Within this process step, lucerne clearly accounts for most of the $20.4 \mathrm{~kg} \mathrm{CO}_{2}$-eq. (40\%), followed by maize grains (18\%), wheat bran (17\%), carrots (13\%), brewer's yeast $(12 \%)$ and on-farm feed processing $(<1 \%)$. GWP from feed ingredients is mainly composed of $\mathrm{CO}_{2}$ (tillage, harvest, plant drying) and $\mathrm{N}_{2} \mathrm{O}$ (cultivation, crop residues). Emissions from lucerne are highest as it is harvested with a DM content of only 33\% (Lucerne producer, pers. comm., 2019 January 17th) resulting in high energy input for drying, whereas maize and wheat are much drier at harvest.

GWP - rearing: Rearing accounts for a little less of total GWP (44\%) and almost all of it comes from heating the rearing facility (93\% of total impacts of rearing). As the average Austrian electricity provision is partially sourced with brown and hard coal as well as natural gas power, especially from Germany and the Czech Republic, mining and natural gas production processes are reflected in the resulting $\mathrm{CO}_{2}$-eq. The production of polypropylene used for the rearing boxes causes relatively little emissions (6\%). GHG emissions from other on-farm machinery such as humidifier, wacker plate and vacuum cleaner, as well as emissions from the mealworms themselves are negligible $(<1 \%)$. Rearingrelated GWP primarily arises as $\mathrm{CO}_{2}$, but also in the form of methane $\left(\mathrm{CH}_{4}\right)$.

GWP-killing \& preserving: Only 7\% of GHG emissions are assigned to killing and preserving: Most of it (88\%) comes from the energy used for blanching the frozen mealworms and only a little (12\%) for the killing (freezing) itself.

The GWP of the overall mealworm production is mainly composed of $\mathrm{CO}_{2}(79 \%), \mathrm{N}_{2} \mathrm{O}(12 \%)$ and $\mathrm{CH}_{4}(8 \%)$.

NREU - feed supply: $44 \%$ of the $213.66 \mathrm{MJ}$-eq of nonrenewable energy used to produce $1 \mathrm{~kg}$ of mealworm protein accounts for feed supply, with lucerne having the greatest share (35\% of diet's NREU). As for GWP, dehydration of the plant primarily accounts for the impacts. Diet-related energy needed for carrot production (mostly harvest related) amounts to $21 \%$ and brewer's yeast accounts for $19 \%$. $13 \%$ falls upon wheat bran due to irrigation, tillage and harvest. Maize accounts for $11 \%$ of diet's emissions share, mostly attributed to the drying of the plant.
Table 3 Environmental impacts of the five studied impact categories from the production of $1 \mathrm{~kg}$ of mealworm protein. The medians as well as the $5^{\text {th }}$ and $95^{\text {th }}$ percentiles of the indicator's probability distri- bution functions based on 1,000 Monte Carlo iterations are presented. Impacts from production of $1 \mathrm{~kg}$ of edible mealworms (chitin-free mass) are added in the right column

\begin{tabular}{|c|c|c|c|c|c|}
\hline \multirow[b]{2}{*}{ Impact category } & \multirow[b]{2}{*}{ Unit } & \multicolumn{3}{|c|}{$1 \mathrm{~kg}$ of edible protein (FU) } & \multirow{2}{*}{$\begin{array}{l}1 \mathrm{~kg} \text { of edible } \\
\text { mass (median) }\end{array}$} \\
\hline & & Median & 5 th percentile & 95th percentile & \\
\hline GWP & {$[\mathrm{kg} \mathrm{CO}$-eq] } & 20.40 & 19.69 & 21.34 & 2.80 \\
\hline NREU & {$[\mathrm{MJ}-\mathrm{eq}]$} & 213.66 & 204.37 & 224.94 & 29.36 \\
\hline ALOP & {$\left[\mathrm{m}^{2}\right]$} & 22.38 & 21.05 & 23.80 & 3.07 \\
\hline TAP & {$\left[\mathrm{g} \mathrm{SO}_{2}\right.$-eq] } & 159.52 & 145.46 & 178.10 & 21.88 \\
\hline FEP & [g P-eq] & 12.41 & 6.22 & 29.97 & 1.71 \\
\hline
\end{tabular}




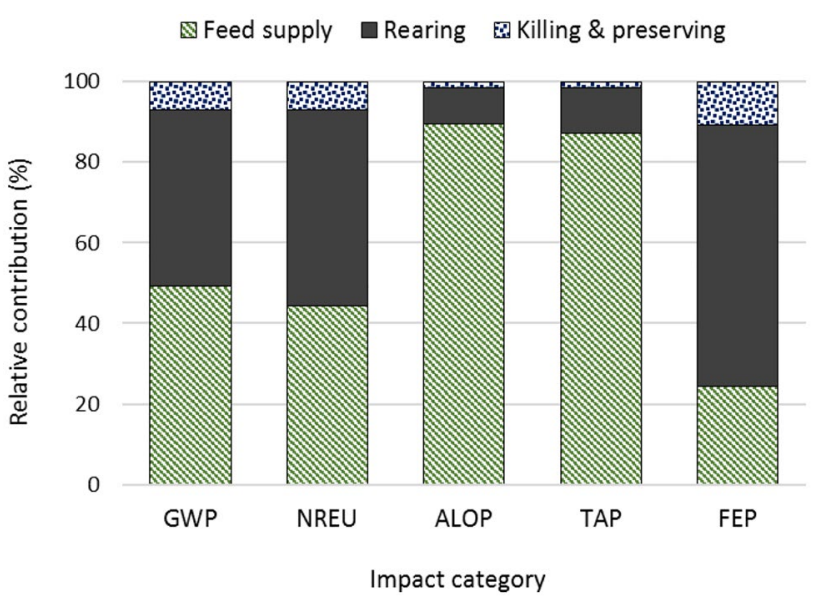

Fig. 4 Relative contributions of different sources in mealworm production to the impact categories global warming potential (GWP), non-renewable energy use (NREU), agricultural land occupation (ALOP), terrestrial acidification potential (TAP) and freshwater eutrophication potential (FEP)

NREU - rearing: Rearing contributes almost half (49\%) of NREU and most of this share (83\%) derives from electricity needed for the electric heater. As for GWP, the mentioned German and Czech fossil energy imports within the Austrian electricity provision is also reflected in the resulting nonrenewable MJ-eq. The remaining energy consumed during rearing $(16 \%)$ is attributed to polypropylene production, whereas other machinery carries no weight.

NREU - killing \& preserving: Killing and preserving contributes in the same way to NREU as to GWP (with 7\%) of which $88 \%$ amounts to the blanching process and $12 \%$ to freezing.

Thanks to the poikilothermic nature of mealworms, the energy in the feed is not used to maintain a constant body temperature, but is directly invested into growth (Nakagaki and Defoliart 1991). However, while poikilothermy decreases the demand for feed, the body temperature of insects depends on the ambient temperature, so the energy consumption of mealworm rearing is high compared to other inputs. The fact that the production is located in a mountainous region at 1,000 $\mathrm{m}$ above sea level, presumably colder outdoor temperatures than for lowlands might have resulted in specifically high heating demands. A change in outdoor temperatures was simulated by the scenario analysis "Colder winter" (see 3.3) which could confirm that the energy demand of insect production systems is influenced by local climatic conditions.

ALOP - feed supply: From the overall $22.38 \mathrm{~m}^{2}$ ascribed to the $1 \mathrm{~kg}$ of $T$. molitor protein production, almost all area (90\%) is occupied by feed supply. Calculated according to crop yield output per hectare, contributions of feed ingredients to the diet's ALOP rank as follows: wheat bran (42\%), maize (22\%), lucerne (20\%) and carrots (16\%).
ALOP - rearing and killing \& preserving: The remaining $10 \%$ of occupied area account for electricity provision, primarily for heating within rearing (9\%) and a negligible amount for the blanching process within killing and preserving $(<2 \%)$. This land use is related to the production of soft- and hardwood forestry for energy provision. The rearing facility itself occupies not even $1 \%$ of overall space needed for producing $1 \mathrm{~kg}$ of mealworm protein. This is because mealworms can be reared in high densities and the rearing boxes are stacked on top of each other.

TAP - feed supply: Feed supply also accounts for the largest share (87\%) of the $159.52 \mathrm{~g} \mathrm{SO}_{2}$-eq. With almost half of it (47\%), wheat cultivation contributes most, as a result of ammonia $\left(\mathrm{NH}_{3}\right)$ emissions from fertilising. Fertilisationrelated $\mathrm{NH}_{3}$ is also the main reason for acidification from maize (34\% of diet-related TAP). For lucerne (10\% share) TAP mainly arises in the form of sulfur dioxides $\left(\mathrm{SO}_{2}\right)$ from dehydration. Harvesting is again responsible for impacts associated with carrot production (7\%), as nitrogen oxides are emitted from tractors. Contributions from $\mathrm{SO}_{2}$ due to heat generation for drying of brewer's yeast are relatively small $(<2 \%)$.

TAP - rearing and killing \& preserving: Rearing accounts for $11 \%$ allotted to heating (91\%) and rearing boxes (8\%). Killing and preserving barely contribute to acidification $(<2 \%)$.

TAP is highly influenced by feed intake, which is why the scenario analysis "Improved FCR" affects these two impact categories most (see 3.3).

FEP - feed supply: Feed supply contributes $24 \%$ to the total of $12.41 \mathrm{~g} \mathrm{P-eq}$ of freshwater eutrophying potential. More than half of it (53\%) comes from coal-power-related phosphate due to the dehydration of lucerne. $19 \%$ is related to carrot cultivation, primarily from erosion of soil particles (phosphorus) but also from soluble phosphate leaching to ground water. Energy for drying maize (14\% of feed related FEP) also contributes to phosphate emissions related to coal mining.

FEP - rearing: Rearing clearly contributes the largest proportion (65\%) to FEP, with almost all of it (99\%) arising from the electric heater. This is again due to fossil fuel used for energy provision, especially the treatment of spoil from lignite mining arising from brown coal industries, which emits substantial amounts of phosphates.

FEP - killing \& preserving: Among all impact categories, the contributions from killing and preserving are largest to freshwater eutrophication (11\%), yet small in comparison to the other sources. Once again, this is caused by phosphate emissions from coal mining for energy production.

As FEP is primarily a result of heating energy supply, it is the impact category that is mostly influenced by the scenario analysis "Colder winter" (see 3.3). 
Table 4 Relative contributions of single processes to total emissions of mealworm production for the five studied impact categories

\begin{tabular}{|c|c|c|c|c|c|}
\hline & GWP & NREU & ALOP & TAP & FEP \\
\hline Sources & {$\left[\mathrm{kg} \mathrm{CO}_{2}\right.$-eq] } & [MJ-eq] & {$\left[\mathrm{m}^{2}\right]$} & {$\left[\mathrm{g} \mathrm{SO}_{2}\right.$-eq] } & [g P-eq] \\
\hline \multicolumn{6}{|l|}{ Feed supply } \\
\hline Wheat bran & $8.48 \%$ & $5.97 \%$ & $37.57 \%$ & $41.21 \%$ & $2.48 \%$ \\
\hline Maize & $8.81 \%$ & $5.05 \%$ & $19.30 \%$ & $29.97 \%$ & $3.32 \%$ \\
\hline Brewer's yeast & $5.78 \%$ & $8.36 \%$ & $<1 \%$ & $1.35 \%$ & $<1 \%$ \\
\hline Lucerne & $19.67 \%$ & $15.52 \%$ & $17.92 \%$ & $8.51 \%$ & $13.13 \%$ \\
\hline Carrots & $6.39 \%$ & $9.26 \%$ & $14.66 \%$ & $6.19 \%$ & $4.66 \%$ \\
\hline Feed processing (on-farm) & $<1 \%$ & $<1 \%$ & $<1 \%$ & $<1 \%$ & $<1 \%$ \\
\hline \multicolumn{6}{|l|}{ Rearing } \\
\hline Electric heater & $40.54 \%$ & $40.79 \%$ & $8.34 \%$ & $10.18 \%$ & $64.80 \%$ \\
\hline Rearing boxes & $2.50 \%$ & $7.86 \%$ & $0 \%$ & $<1 \%$ & $<1 \%$ \\
\hline Other machinery & $<1 \%$ & $<1 \%$ & $<1 \%$ & $<1 \%$ & $<1 \%$ \\
\hline Rearing facility & $0 \%$ & $0 \%$ & $<1 \%$ & $0 \%$ & $0 \%$ \\
\hline Mealworm emissions & $<1 \%$ & $0 \%$ & $0 \%$ & $<1 \%$ & $0 \%$ \\
\hline \multicolumn{6}{|l|}{ Killing \& preserving } \\
\hline Freezing & $<1 \%$ & $<1 \%$ & $<1 \%$ & $<1 \%$ & $1.36 \%$ \\
\hline Blanching & $6.17 \%$ & $6.17 \%$ & $1.26 \%$ & $1.41 \%$ & $9.39 \%$ \\
\hline Total & $100 \%$ & $100 \%$ & $100 \%$ & $100 \%$ & $100 \%$ \\
\hline
\end{tabular}

Table 4 summarises the relative contributions of single processes to total emissions according to the five studied impact categories.

\subsection{Organic broiler system}

The potential environmental impacts associated with organic broiler production are presented in Table 5 .

The production of $1 \mathrm{~kg}$ of edible broiler protein $(\mathrm{FU})$ resulted in $26.59 \mathrm{~kg} \mathrm{CO}_{2}$-eq of global warming potential (GWP) whereas feed supply and storage of broiler manure take the largest shares. $259 \mathrm{MJ}-\mathrm{eq}$ of non-renewable energy use (NREU) is by more than half required for feed production and processing, but also for heating the system. 73.56 $\mathrm{m}^{2}$ of agricultural land occupation (ALOP) is ascribed primarily to feed cultivation. $579.71 \mathrm{~g} \mathrm{SO}_{2}$-eq of terrestrial acidification potential (TAP) arise particularly from manure management in buildings, outdoor run and storage. $11.61 \mathrm{~g}$

Table 5 Environmental impacts of the five studied impact categories from the production of $1 \mathrm{~kg}$ of broiler protein. The medians as well as the 5th and 95th percentiles of the indicator's probability distribu-
P-eq of freshwater eutrophication potential (FEP) derive to the largest part from fertilising the feed crops. Relative contributions of the broiler system are further discussed and illustrated in 3.4.

\subsection{Scenario analyses}

"Improved FCR": Firstly, it has been tested how dependent the estimated impacts are on feed input quantities. FCR of the current mealworm production system is 3.61 (see 2.2.1). An improvement of FCR is feasible, as two investigated industrial T. molitor productions indicate FCRs of 2.19 (Oonincx and de Boer 2012) and 1.98 (Thévenot et al. 2018). The mean from these two studies was taken as FCR for this scenario analysis depicted in Fig. 5.

An improved FCR, i.e. a change from FCR of 3.61 to FCR of 2.10 , resulted in a reduced $(-42 \%)$ feed intake. As illustrated in Fig. 5, all potential environmental

tion functions based on 1,000 Monte Carlo iterations are presented. Impacts from production of $1 \mathrm{~kg}$ of edible broiler (boneless meat) are added in the right column

\begin{tabular}{|c|c|c|c|c|c|}
\hline \multirow[b]{2}{*}{ Impact category } & \multirow[b]{2}{*}{ Unit } & \multicolumn{3}{|c|}{$1 \mathrm{~kg}$ of edible protein $(\mathrm{FU})$} & \multirow{2}{*}{$\begin{array}{l}1 \mathrm{~kg} \text { of edible } \\
\text { meat (median) }\end{array}$} \\
\hline & & Median & $5^{\text {th }}$ percentile & 95th percentile & \\
\hline GWP & {$\left[\mathrm{kg} \mathrm{CO}_{2}\right.$-eq] } & 26.59 & 22.79 & 31.86 & 4.50 \\
\hline NREU & [MJ-eq] & 259.00 & 214.31 & 315.50 & 43.96 \\
\hline ALOP & {$\left[\mathrm{m}^{2}\right]$} & 73.56 & 56.10 & 99.14 & 12.48 \\
\hline TAP & {$\left[\mathrm{g} \mathrm{SO}_{2}\right.$-eq] } & 579.71 & 552.03 & 622.92 & 98.37 \\
\hline FEP & [g P-eq] & 11.61 & 7.89 & 19.34 & 1.96 \\
\hline
\end{tabular}


Fig. 5 Scenario analysis for actual versus improved (-42\%) feed consumption
Current system (FCR 3.61) @ Improved FCR (FCR 2.1)

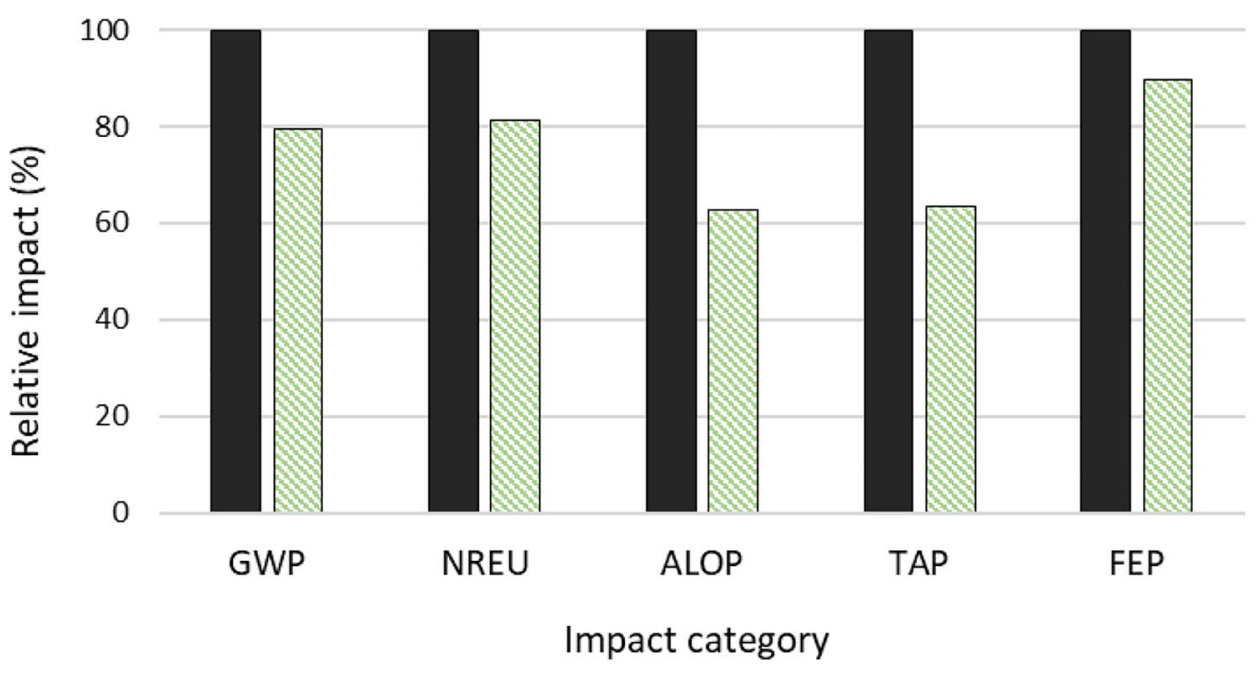

impacts were positively influenced, ranging from at least $11 \%$ reduction for FEP to $37 \%$ reduction for ALOP and TAP. Scenario analysis showed that reduced feed intake could significantly improve the sustainability traits studied, almost approximating reported LCAperformance of Dutch mealworms (Oonincx and de Boer 2012).

"Colder winter": Secondly, it has been tested how sensitive the system is to outdoor temperatures by evaluating the effects of severe weather conditions on energy use. As indicated above, heating electricity (equivalent to four months of fully heating) accounted for 10.38 MJ. Assuming the conditions of January 2019 (ZAMG 2019) throughout the entire winter, a worst case scenario of six months fully heating would amount to $15.86 \mathrm{MJ}$ of energy demanded by the electric heater ( $50 \%$ increase).

As illustrated in Fig. 6 a "Colder winter", i.e. increasing heating energy demand by $50 \%$, resulted in increases of $34 \%$ to FEP, $21 \%$ to both GWP and NREU, whereas TAP and ALOP were hardly affected ( $5 \%$ and $4 \%$, respectively). This confirms that energy-related impact categories are clearly influenced by outdoor weather conditions. Obviously, regions of higher latitudes such as Europe and North America require more heating than e.g. tropical regions, where high temperatures throughout the year might allow for not heating the rearing facilities at all. Therefore, geographical location is one of the main determinants for energy requirements of the system.
Fig. 6 Scenario analysis for current vs. lower outdoor temperatures, leading to increased energy demand for heating $(+50 \%)$
- Current system (Austrian winter temp. at 1,000 m sea level) $⿴$ Colder winter

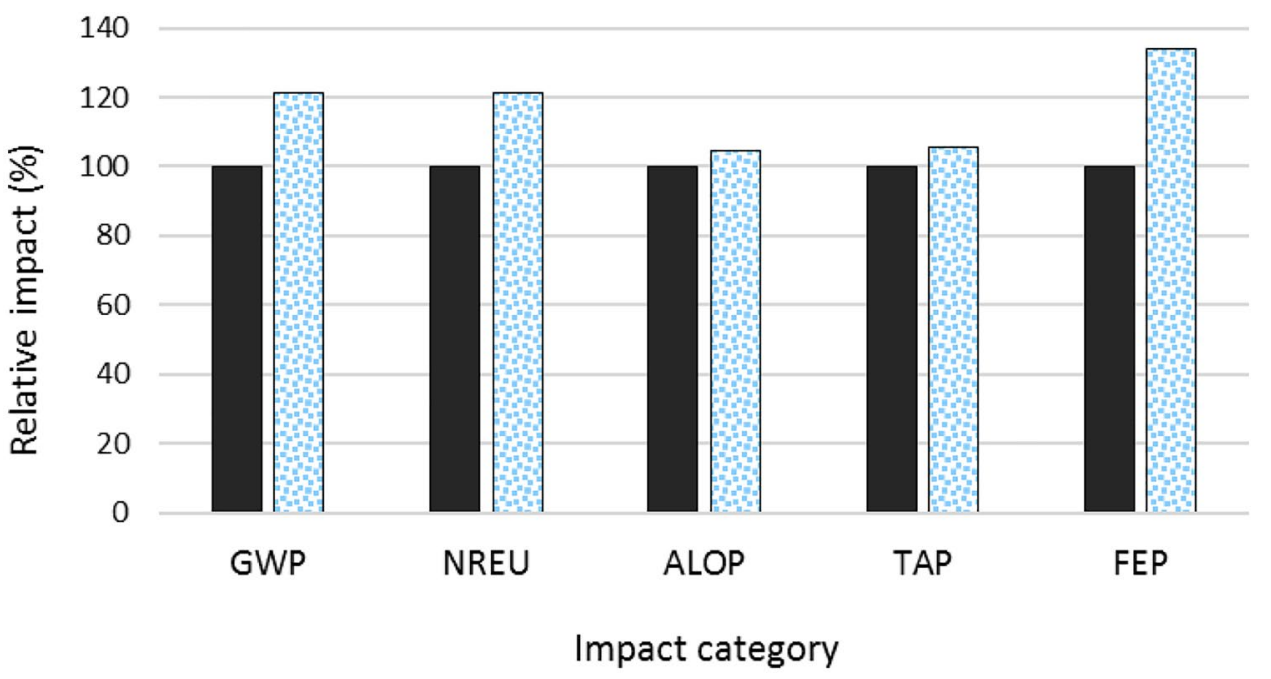




\subsection{System comparison}

In the following, the production of mealworm and broiler protein are compared. Figure 7 illustrates the systemic differences according to each impact category by indicating the share of the lower-impacting system in relation to the higher-impacting system, $100 \%$ assigned to the latter.

As can be seen in Fig. 7, the production of mealworm protein causes less potential environmental impacts than the production of the same quantity of broiler protein with regard to the impact categories covered herein-with the exception of FEP. Mealworm production releases 23\% less GHG emissions (GWP), uses $18 \%$ less non-renewable energy (NREU), occupies 70\% less agricultural land (ALOP) and causes 72\% less terrestrial acidification (TAP). Yet, $6 \%$ more freshwater eutrophying emissions (FEP) are caused by mealworms in comparison to broiler production.

Relative contributions from the three production stages to GWP seem similar for both systems. However, while mealworm rearing contributes primarily with emissions related to heating energy (93\%), GWP from growing-fattening broilers arises not only from heating, electricity and infrastructure (54\%) but to a large part from $\mathrm{N}_{2} \mathrm{O}$ and $\mathrm{CH}_{4}$ due to broiler manure management (45\%). Higher heating demands for T. molitor production is more than compensated by lower impacts associated with feed intake and killing process resulting in lower overall NREU. In terms of ALOP, mealworms clearly outperform broilers because broiler feed (with highest burdens from soybean, maize and wheat) accounts for more arable land than mealworm feed. One of the main reasons for the mealworm diet occupying less arable land than that for broilers is that wheat bran was allocated economically as a by-product of wheat flour. Also, less feed is needed by mealworms $(3.61 \mathrm{~kg})$ than by broilers $(4.91 \mathrm{~kg})$ for producing the same amount of edible mass. In addition, as broilers are farmed organically, they are provided with more space in- and outdoors. Mealworms, as mentioned, can be reared in high densities and the rearing boxes are vertically stacked. This leads to very little space requirements within the rearing facility. An even bigger difference, in favour of mealworms, occurs for TAP: Terrestrial acidifying emissions are more than three times higher for broilers, mainly because of considerable $\mathrm{NH}_{3}$ emissions related to fermentation of uric acid in the broiler manure. As indicated, freshwater eutrophication steps out of the general line: A higher heat demand in the mealworm rearing system leads to higher FEP, due to phosphate emissions related to fossil energy from Germany and the Czech Republic. As FEP is afflicted with high uncertainties, system comparison of this impact category should be treated with caution.

\subsection{Comparison with literature}

When comparing the results of the Austrian mealworm system to previous LCA studies on edible insects, Oonincx and de Boer (2012) investigated a Dutch T. molitor production system
Fig. 7 Comparison of the two production systems according to the five impact categories. Mealworm production is indicated on the left-hand columns (with sources "feed supply", "rearing" and "killing \& preserving"), while broiler production appears on the respective right-hand side ("feed supply", "growing-fattening" and "slaughtering \& preserving"). Based on 1,000 Monte Carlo iterations, all categories are significantly different when tested with a Mann-Whitney $U$ test which is indicated by the labels $a$ and $b$ for every impact category

\section{Feed supply $\quad$ Rearing / Growing-fattening Killing / Slaughtering}

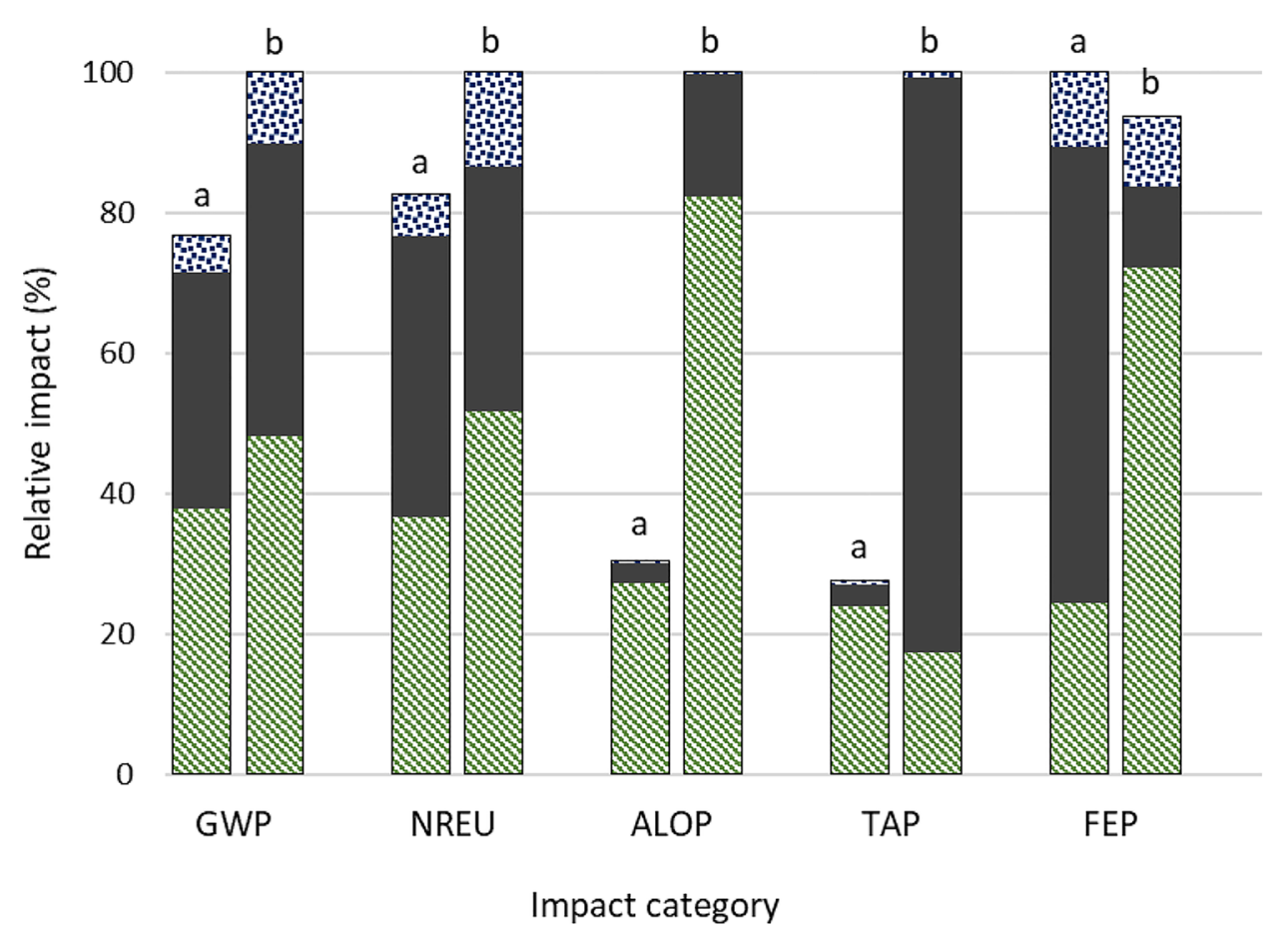


and indicated a lower protein-related GWP ( $31 \%$ as compared to this study), fossil energy use (19\% less) and land use (20\% less). Based on production input data from Oonincx and de Boer (2012) and Oonincx et al. (2015), Joensuu and Silvenius (2017) modelled a potential industrial-scale mealworm production for human consumption in Finland. Thévenot et al. (2018) performed an LCA of a French mealworm meal production system (with system boundary at the mill gate), so comparison is only possible for fresh products (farm gate). Reported results for GWP, CED and land use are 48-65\% lower than the impacts found in the current study. Lower GWP and energy use, also in comparison to the Dutch mealworm production, are explained particularly by energy provision: While electricity in France (Thévenot et al. 2018) is mostly sourced from nuclear power, the Dutch system mainly relies on natural gas. Reasons for varying land consumption are differences in feed composition, which are not always disclosed by the studies, due to company secret. The main reasons why the Austrian mealworm production system performs worse when compared to previous insect LCAs appear to be (1) smaller scale of production, (2) lower feed conversion efficiency and (3) the type of production system.

(1) The mealworm and cricket production systems compared are medium to large-scale, with several tons of weekly output, whereas the system studied herein produces less than a ton per year. Environmental impacts can be reduced by increased production volumes and improved production efficiency (van Huis and Tomberlin 2017; Smetana et al. 2019).

(2) An FCR of 3.61 was found for the Austrian mealworm production system, which is substantially higher than values from previous insect LCAs, which were in the range of 1.98 to 2.19 (Oonincx and de Boer 2012; Thévenot et al. 2018; Halloran et al. 2017). Differences in production scale might to some extent explain different conversion efficiencies as $T$. molitor reared in labs and with comparable feed intake were observed to have FCR values no better than 5.0 (Oonincx et al. 2015).

(3) The system studied herein represents an organic production system, mostly reflected by organic feed ingredients, while the compared production systems utilize conventional feedstuffs. Usually, crops from organic farming are characterised by lower yields per hectare than conventional crops, leading to higher land consumption, while other impact categories need a more differentiated analysis.

When comparing the results of the selected Austrian broiler system with published values, literature search was focused on LCAs from European organic chicken meat productions including at least two farms, cradle-to-farm gate boundaries and the categories GWP, energy use, acidification and eutrophication. Compared to production of $1 \mathrm{~kg}$ of organic meat (protein-based values are scarce), the studied broiler production system performs well: The GWP of $4.50 \mathrm{~kg} \mathrm{CO}_{2}$-eq compares favourably with systems from
Switzerland (6.40) (Alig et al. 2012; Wolff et al. 2016), the UK (6.68) (Williams et al. 2006) and, again, the UK (5.66) (Leinonen et al. 2012). Data on energy use are not as straight forward, as they depend on the type of energy used. Comparable primary energy use for UK broiler production is indicated as $40.34 \mathrm{MJ}$ per kg edible meat at farm gate (slaughtering excluded) (Leinonen et al. 2012) which is slightly lower than the NREU of $43.96 \mathrm{MJ}$-eq of this study. The Swiss broiler system including the slaughtering gate, however, showed a non-renewable energy use of 77.20 MJ-eq (Alig et al. 2012; Wolff et al. 2016). Agricultural land occupation for crop production is reported to be $14 \mathrm{~m}^{2}$ (Williams et al. 2006) and $25 \mathrm{~m}^{2}$ (Leinonen et al. 2012) taking up more land per kg of broiler meat than the here studied system (12.48 $\mathrm{m}^{2}$ ). The English systems also report results for acidification potential of $264 \mathrm{~g} \mathrm{SO}_{2}$-eq (Williams et al. 2006) and $91.55 \mathrm{~g}$ $\mathrm{SO}_{2}$-eq (Leinonen et al. 2012). Taking into account that the latter value excludes slaughtering, the TAP of 98.37 of this study is well able to keep up. The same applies to eutrophication potential when comparing the FEP of $1.96 \mathrm{~g}$ P-eq of this study with reported results of $25.80 \mathrm{~g}$ P-eq (Williams et al. 2006) and $14.65 \mathrm{~g}$ (Leinonen et al. 2012). It can be concluded that the selected Austrian broiler production system has relatively low impacts, which confirms the conservative assumptions and the approach of comparing the main system of mealworm production with an actual possible, highly productive and relatively efficient broiler system.

\subsection{Limitations of this LCA study}

The investigated system considered cradle-to-gate boundaries, meaning that after killing the mealworms no downstream processing stages were observed. However, if not eaten fresh, freeze-drying represents the current industrial drying technique for stabilising mealworms (EFSA 2015), which has high implications to all energy-related impacts and could significantly downgrade the environmental performance of the LCA conducted. Alternatives such as microwave drying have been suggested already (Lenaerts et al. 2018). Therefore, in terms of energy consumption and associated emissions, the treatment of freeze-drying should be either further optimised or avoided completely.

Direct on-farm emissions related to mealworms and their excretions couldn't be quantified at the production site, which is why experimental data were taken from Oonincx et al. (2010). So far, however, little data exist regarding the production of gases from insects (Salomone et al. 2017): Hackstein and Stumm (1994) first indicated that mealworms do not produce methane $\left(\mathrm{CH}_{4}\right)$. Oonincx et al. (2010) confirmed the absence of $\mathrm{CH}_{4}$ and showed that they compare favourably with traditional livestock production in terms of both $\mathrm{N}_{2} \mathrm{O}$ and $\mathrm{NH}_{3}$ emissions. Since then, however, most insect LCAs - including the one presented herein - have 
relied on N-related emission data from Oonincx et al. (2010). Therefore, in-situ measurements need to be carried out in follow-up studies. If fed on common protein rich sources like in this study, insects do not use microbes to breakdown their feed. However, when fed on sources containing cellulose compounds (such as grass cuttings or garden waste), attention has to be payed to the risk of $\mathrm{CH}_{4}$ emissions from methanogenic bacteria (Halloran et al. 2018).

Mealworms were benchmarked to broilers as chicken meat - in terms of production efficiency - is frequently considered the most sustainable meat alternative among traditional livestock products, which make up $67 \%$ of total Austrian protein supply (calculated based on Rust et al. 2017).

It has to be noted that FCR only calculates conversion rates of the initial feed input but doesn't ask what specifically is being converted. Monogastric poultry and pigs with digestive systems similar to those of humans are very dependent on cereal and oilseed-based diets that could be in large parts consumed directly by humans (Garnett 2009). Ruminants, on the contrary, are capable of converting human-inedible fibrous plant material into high-quality animal products and, if feed is not competing with food, they can be considered net food producers (Ertl et al. 2015).

The issue of feed potentially competing with food is not reflected in the present LCA. Nevertheless, insects might be even better converters than ruminants, as they can be used to convert a wide range of organic materials such as food waste (Varelas 2019), manure (Roffeis et al. 2015; van Zanten et al. 2015) or even polystyrene (Peng et al. 2019) into edible proteins. If reared on non-utilised by-products or waste-streams, no or only very little agricultural land is required for feed crop cultivation, resulting in minimum overall land occupation. In this way, insect products could even outperform sustainability of plant protein production systems. As agricultural land becomes scarce, it is argued that land use might become more important than other inputs such as heating energy, which in the best case could be supplied with residual heat from adjacent production systems (Salomone et al. 2017). The most promising advantage of insects could be their ability to convert materials metabolically unavailable to vertebrates into high-quality proteins, i.e. increasing overall food availability by upgrading waste to food.

\section{Conclusions}

With regard to the initially raised questions it can be concluded that: (1) The potential environmental impacts related to the production of $1 \mathrm{~kg}$ of edible mealworm protein are $20.4 \mathrm{~kg} \mathrm{CO}_{2}$-eq (GWP), 213.66 MJ-eq (NREU), $22.38 \mathrm{~m}^{2}$ (ALOP), $159.52 \mathrm{~g} \mathrm{SO}_{2}$-eq (TAP) and $12.41 \mathrm{~g} \mathrm{P}$-eq (FEP). (2) Environmental hot-spots along the mealworm production chain are upstream feed production (mainly cultivation and drying of harvested feedstuffs) and on-farm energy demand related to the heating of the facilities. Depending on the impact category, feed supply contributes up to $90 \%$, whereas rearing (which is $83-99 \%$ determined by heating) accounts for up to $65 \%$ of overall impacts. Both findings are supported by scenario analyses conducted with changed parameters for feed intake and heating input. (3) When contrasted with the selected Austrian organic broiler production system, mealworms compare favourably regarding all impact categories (18-72\% lower impacts), with the exception of freshwater eutrophication (6\% higher impacts). The overall superior performance of $T$. molitor is mainly explained by higher feed conversion efficiencies (mainly as a result of higher edible portion), negligible direct and indirect GHG emissions from mealworms and little requirements within the rearing facilities when compared to broiler housing systems, with the exception of heat dependency.

The Austrian mealworm production system compares favourably with traditional livestock systems, but as it operates on a small scale and obtains organic feed ingredients, it cannot compete with more efficient large-scale T. molitor production systems for the impact categories covered herein. Nevertheless, it is suggested that the investigated system produces a sustainable protein alternative that should be adopted by Western countries.

Acknowledgements Gratitude is owed to the BOKU university laboratories of the Institute of Animal Nutrition, Livestock Products, and Nutrition Physiology (TTE) as well as the Institute of Soil Research (IBF) for analysing nutritional values of the various mealworm samples.

Funding Open access funding provided by University of Natural Resources and Life Sciences Vienna (BOKU).

Open Access This article is licensed under a Creative Commons Attribution 4.0 International License, which permits use, sharing, adaptation, distribution and reproduction in any medium or format, as long as you give appropriate credit to the original author(s) and the source, provide a link to the Creative Commons licence, and indicate if changes were made. The images or other third party material in this article are included in the article's Creative Commons licence, unless indicated otherwise in a credit line to the material. If material is not included in the article's Creative Commons licence and your intended use is not permitted by statutory regulation or exceeds the permitted use, you will need to obtain permission directly from the copyright holder. To view a copy of this licence, visit http://creativecommons.org/licenses/by/4.0/.

\section{References}

Alig M, Grandl F, Mieleitner J et al (2012) Ökobilanz von Rind-, Schweine-und Geflügelfleisch. Forschungsanstalt Agroscope Reckenholz-Tänikon ART, Zürich 
Barker Dayna, Fitzpatrick Marianne P., Dierenfeld Ellen S. (1998) Nutrient composition of selected whole invertebrates. Zoo Biol 17(2):123-134.

Bellof G, Schmidt E (2007) Ökologische GeflügelmastLösungsmöglichkeiten für eine 100\% Bio-Fütterung. In: Wiesinger $\mathrm{K}$ (ed) Angewandte Forschung und Beratung für den ökologischen Landbau in Bayern, Schriftenreihe der Bayerischen Landesanstalt für Landwirtschaft (LfL), Freising. Freising, pp 23-33

BIO AUSTRIA (2015) Haltungsbestimmungen für Bio-Masthühner entsprechend der EU-Bio-Verordnung

Cesari V, Zucali M, Sandrucci A et al (2017) Environmental impact assessment of an Italian vertically integrated broiler system through a Life Cycle approach. J Clean Prod 143:904-911. https:// doi.org/10.1016/j.jclepro.2016.12.030

de Vries M, de Boer IJM (2010) Comparing environmental impacts for livestock products: A review of life cycle assessments. Livest Sci 128:1-11. https://doi.org/10.1016/j.livsci.2009.11.007

Dreyer M (2019) Environmental impact assessment of yellow mealworm (T. molitor) production for human nutrition in Austria. Master thesis, University of Natural Resources and Life Sciences, Vienna

Ecoinvent (2015) Ecoinvent data v3.2. Swiss centre for life cycle inventories. https://www.ecoinvent.org/. Accessed 20 Dec 2020

EFSA (2015) Risk profile related to production and consumption of insects as food and feed: Risk profile of insects as food and feed. EFSA J 13:4257. https://doi.org/10.2903/j.efsa.2015.4257

Ertl P, Klocker H, Hörtenhuber S et al (2015) The net contribution of dairy production to human food supply: The case of Austrian dairy farms. Agric Syst 137:119-125. https://doi.org/10.1016/j. agsy.2015.04.004

FAO (2017) Food Balance Sheets: Meat - Food Supply Quantity. http:// www.fao.org/faostat/en/\#data. Accessed 20 Dec 2020

Gac A, Tribot-Laspière P, Scislowski V et al (2012) Recherche de méthodes d'évaluation de l'expression de l'empreinte carbone des produits viande. Institut de L'elevage - Département Technique d'Élevage et Qualité

Garnett T (2009) Livestock-related greenhouse gas emissions: impacts and options for policy makers. Environ Sci Policy 12:491-503. https://doi.org/10.1016/j.envsci.2009.01.006

Gerber PJ, FAO (eds) (2013) Tackling climate change through livestock: a global assessment of emissions and mitigation opportunities. Food and Agriculture Organization of the United Nations, Rome

Goedkoop MJ, Heijungs R, Huijbregts M et al (2008) ReCiPe 2008: A life cycle impact assessment method which comprises harmonised category indicators at the midpoint and the endpoint level

Grau T, Vilcinskas A, Joop G (2017) Sustainable farming of the mealworm Tenebrio molitor for the production of food and feed. Zeitschrift Für Naturforschung C 72:337-349. https://doi.org/10. 1515/znc-2017-0033

Green Delta GmbH (2019) openLCA (Version 1.9, 2019). www.openlca. org. Accessed 20 Dec 2020

Guinée JB (2002) Handbook on life cycle assessment: Operational Guide to the ISO Standards. Kluwer Academic Publishers, New York, Boston; Dordrecht; London; Moscow

Hackstein JH, Stumm CK (1994) Methane production in terrestrial arthropods. PNAS 91:5441-5445. https://doi.org/10.1073/pnas. 91.12.5441

Halloran A, Flore R, Vantomme P, Roos N (eds) (2018) Edible Insects in Sustainable Food Systems. Springer International Publishing, Cham

Halloran A, Hanboonsong Y, Roos N, Bruun S (2017) Life cycle assessment of cricket farming in north-eastern Thailand. J Clean Prod 156:83-94. https://doi.org/10.1016/j.jclepro.2017.04.017

Herrero M, Havlik P, Valin H et al (2013) Biomass use, production, feed efficiencies, and greenhouse gas emissions from global livestock systems. Proc Natl Acad Sci 110:20888-20893. https:// doi.org/10.1073/pnas.1308149110

Herrero M, Henderson B, Havlík P et al (2016) Greenhouse gas mitigation potentials in the livestock sector. Nat Clim Chang 6:452-461. https://doi.org/10.1038/nclimate2925

Hörtenhuber S, Zollitsch W (2016) Evaluierung langsam wachsender genetischer Herkünfte bei Masthühnern im Hinblick auf Produktqualität, Ökobilanz und Wirtschaftlichkeit - Kapitel Ökobilanz und Wirtschaftlichkeit. BOKU - University of Natural Resources and Life Sciences, Department of Animal Sciences, Vienna

IBM Corp (2016) IBM SPSS Statistics for Windows. Version 24.0. IBM Corp., Armonk, New York

IPCC (2013) Climate Change 2013: The Physical Science Basis: Working Group I Contribution to the Fifth Assessment Report of the Intergovernmental Panel on Climate Change. Cambridge University Press, New York

ISO (2006a) ISO 14040:2006: Environmental management - life cycle assessment - principles and framework. ISO, Geneva, Switzerland

ISO (2006b) ISO 14044:2006: Environmental management - life cycle assessment - requirements and guidelines. ISO, Geneva, Switzerland

Joensuu K, Silvenius F (2017) Production of mealworms for human consumption in Finland: a preliminary life cycle assessment. J Insects Food Feed 3:211-216. https://doi.org/10.3920/JIFF2016.0029

Jongema Y (2015) World List of Edible Insects 2015. https://www.wur. nl/upload_mm/7/4/1/ca8baa25-b035-4bd2-9fdc-a7df1405519a WORLD\% 20LIST\%20EDIBLE\%20INSECTS\% 202015.pdf. Accessed 20 Dec 2020

Koch P, Salou T (2016) AGRIBALYSE®: Rapport Méthodologique Version 1.3. Angers, France

Kral I, Piringer G, Saylor MK et al (2016) Environmental Effects of Steam Explosion Pretreatment on Biogas from Maize-Case Study of a 500-kW Austrian Biogas Facility. BioEnergy Research 9:198-207. https://doi.org/10.1007/s12155-015-9676-0

KTBL (ed) (2015) Faustzahlen für den Ökologischen Landbau. Kuratorium für Technik und Bauwesen in der Landwirtschaft e.V. (KTBL), Darmstadt

Leinonen I, Williams AG, Wiseman J et al (2012) Predicting the environmental impacts of chicken systems in the United Kingdom through a life cycle assessment: Broiler production systems. Poult Sci 91:8-25. https://doi.org/10.3382/ps.2011-01634

Lenaerts S, Van Der Borght M, Callens A, Van Campenhout L (2018) Suitability of microwave drying for mealworms (Tenebrio molitor) as alternative to freeze drying: Impact on nutritional quality and colour. Food Chem 254:129-136. https://doi.org/10. 1016/j.foodchem.2018.02.006

LfL (2018) Festmistanfall verschiedener Tierarten in $\mathrm{t}$ bzw. $\mathrm{m}^{3}$ pro mittlerem Jahresbestand in Abhängigkeit von Leistung und Fütterung. https://www.lfl.bayern.de/iab/duengung/031245/https:// www.lfl.bayern.de/iab/duengung/031245/ Accessed 20 Dec 2020

Miglietta P, De Leo F, Ruberti M et al (2015) Mealworms for Food: A Water Footprint Perspective. Water 7:6190-6203. https://doi. org/10.3390/w7116190

Nakagaki BJ, Defoliart GR (1991) Comparison of Diets for MassRearing Acheta domesticus (Orthoptera: Gryllidae) as a Novelty Food, and Comparison of Food Conversion Efficiency with Values Reported for Livestock. J Econ Entomol 84:891-896. https://doi. org/10.1093/jee/84.3.891

Ng WK, Liew FL, Ang LP, Wong KW (2001) Potential of mealworm (Tenebrio molitor) as an alternative protein source in practical diets for African catfish, Clarias gariepinus. Aquacul Res 32:273-280

Notarnicola B, Salomone R, Petti L et al (eds) (2015) Life Cycle Assessment in the Agri-food Sector. Springer International Publishing, Cham 
Oberascher C, Stamminger R, Pakula C (2011) Energy efficiency in daily food preparation. Int J Consum Stud 35:201-211

Oonincx DGAB, De Boer IJ (2012) Environmental Impact of the Production of Mealworms as a Protein Source for Humans - A Life Cycle Assessment. PLoS ONE 7:e51145. https://doi.org/10.1371/ journal.pone.0051145

Oonincx DGAB, van Itterbeeck J, Heetkamp MJW et al (2010) An Exploration on Greenhouse Gas and Ammonia Production by Insect Species Suitable for Animal or Human Consumption. PLoS ONE 5:e14445. https://doi.org/10.1371/journal.pone.0014445

Oonincx DGAB, van Broekhoven S, van Huis A, van Loon JJA (2015) Feed Conversion, Survival and Development, and Composition of Four Insect Species on Diets Composed of Food By-Products. PLoS ONE 10:e0144601. https://doi.org/10.1371/journal.pone. 0144601

Payne CLR, Scarborough P, Rayner M, Nonaka K (2016) A systematic review of nutrient composition data available for twelve commercially available edible insects, and comparison with reference values. Trends Food Sci Technol 47:69-77. https://doi.org/10.1016/j. tifs.2015.10.012

Peng B-Y, Su Y, Chen Z et al (2019) Biodegradation of Polystyrene by Dark (Tenebrio obscurus) and Yellow (Tenebrio molitor) Mealworms (Coleoptera: Tenebrionidae). Environ Sci Technol 53:5256-5265. https://doi.org/10.1021/acs.est.8b06963

Poelaert C, Francis F, Alabi T et al (2018) Protein value of two insects, subjected to various heat treatments, using growing rats and the protein digestibility-corrected amino acid score. J Insects Food Feed 4:77-87. https://doi.org/10.3920/JIFF2017.0003

Roffeis M, Muys B, Almeida J et al (2015) Pig manure treatment with housefly (Musca domestica) rearing - an environmental life cycle assessment. J Insects Food Feed 1:195-214. https://doi.org/10. 3920/JIFF2014.0021

Rust P, Hasenegger V, König J (2017) Österreichischer Ernährungsbericht 2017. Universität Wien und Bundesministerium für Gesundheit und Frauen, Wien

Salomone R, Saija G, Mondello G et al (2017) Environmental impact of food waste bioconversion by insects: Application of Life Cycle Assessment to process using Hermetia illucens. J Clean Prod 140:890-905. https://doi.org/10.1016/j.jclepro.2016.06.154

Schmidt E, Bellof G, Einhellig K, Brandl M (2009) Divergierende Genotypen in der ökologischen Hähnchenmast. LfL-Schriftenreihe Nr. 7, Freising-Weihenstephan, pp 7-16

Searchinger T, Hanson C, Ranganathan J et al (2014) Creating a sustainable food future: A menu of solutions to sustainably feed more than 9 billion people by 2050. World resources report 2013-14 : interim findings

Smetana S, Palanisamy M, Mathys A, Heinz V (2016) Sustainability of insect use for feed and food: Life Cycle Assessment perspective. J Clean Prod 137:741-751. https://doi.org/10.1016/j.jclepro. 2016.07.148

Smetana S, Schmitt E, Mathys A (2019) Sustainable use of Hermetia illucens insect biomass for feed and food: Attributional and consequential life cycle assessment. Resour Conserv Recycl 144:285296. https://doi.org/10.1016/j.resconrec.2019.01.042

Steinfeld H, Gerber P, Wassenaar TD et al (2006) Livestock's long shadow: environmental issues and options. Food and Agriculture Organization of the United Nations, Rome
Thévenot A, Rivera JL, Wilfart A et al (2018) Mealworm meal for animal feed: Environmental assessment and sensitivity analysis to guide future prospects. J Clean Prod 170:1260-1267. https:// doi.org/10.1016/j.jclepro.2017.09.054

Tilman D, Clark M (2014) Global diets link environmental sustainability and human health. Nature 515:518-522. https://doi.org/ 10.1038/nature13959

United Nations (2017) World Population Prospects: The 2017 Revision: Key Findings \& Advance Tables. Department of Economic and Social Affairs: Population Devision, New York

van Huis A, Tomberlin JK (eds) (2017) Insects as food and feed: from production to consumption. Wageningen Academic Publishers, Wageningen

van Huis A, Van Itterbeeck J, Klunder H et al (2013) Edible insects: future prospects for food and feed security. Food and Agriculture Organization of the United Nations, Rome

van Zanten HHE, Mollenhorst H, Oonincx DGAB et al (2015) From environmental nuisance to environmental opportunity: housefly larvae convert waste to livestock feed. J Clean Prod 102:362-369. https://doi.org/10.1016/j.jclepro.2015.04.106

Van Zeist WJ, Marinussen M, Broekema R, et al (2012) LCI data for the calculation tool Feedprint for greenhouse gas emissions of feed production and utilization: other products

Varelas (2019) Food Wastes as a Potential new Source for Edible Insect Mass Production for Food and Feed: A review. Fermentation 5:81. https://doi.org/10.3390/fermentation5030081

Williams A, Audsley E, Jones R et al (2006) Determining the environmental burdens and resource use in the production of agricultural and horticultural commodities. Main report. Defra research project IS0205. Cranfield University and Defra, Bedford

Wolf M-A, Pant R, Sala S (2012) Characterisation factors of the ILCD Recommended Life Cycle Impact Assessment methods. Database and supporting information. European Commission - Joint Research Centre - Institute for Environment and Sustainability, Luxembourg

Wolff V, Alig M, Nemecek T, Gaillard G (2016) Ökobilanz verschiedener Fleischprodukte. Geflügel-, Schweine- und Rindfleisch. Agroscope, Zürich

World Resources Institute (2013) The Great Balancing Act. https:// www.wri.org/resources/data-visualizations/great-balancing-act. Accessed 20 Dec 2020

ZAMG (2018a) Oktober 2018: sehr mild, im Norden trocken, im Süden sehr nass. https://www.zamg.ac.at/cms/de/klima/news/ oktober-2018-sehr-mild-im-norden-trocken-im-sueden-sehr-nass. Accessed 20 Dec 2020

ZAMG (2018b) November 2018: trocken und mild. https://www.zamg. ac.at/cms/de/wetter/news/november-2018-trocken-und-mild. Accessed 20 Dec 2020

ZAMG (2019) Auf den Bergen kältester Jänner seit über 30 Jahren. https://www.zamg.ac.at/cms/de/klima/news/auf-den-bergenkaeltester-jaenner-seit-ueber-30-jahren. Accessed 20 Dec 2020

Publisher's Note Springer Nature remains neutral with regard to jurisdictional claims in published maps and institutional affiliations. 


\section{Authors and Affiliations}

Moritz Dreyer $^{1}$ - Stefan Hörtenhuber ${ }^{2} \cdot$ Werner Zollitsch $^{2} \cdot$ Henry Jäger $^{3} \cdot$ Lisa-Marie Schaden $^{4} \cdot$ Andreas Gronauer $^{1}$. Iris $\mathrm{Kral}^{1}$ (1)

1 Institute of Agricultural Engineering, University of Natural Resources and Life Sciences, Vienna, Austria

2 Division of Livestock Sciences, University of Natural Resources and Life Sciences, Vienna, Austria
3 Institute of Food Technology, University of Natural Resources and Life Sciences, Vienna, Austria

4 Die Wurmfarm, Bad St. Leonhard, Austria 